ks. Dominik Kubicki

Uniwersytet im. A. Mickiewicza w Poznaniu

\title{
Kontemplatywna głębia wiary Trójjedynemu w spełnianiu się $w$ jestestwie - rozstrzygnięciem współczesnego dylematu postmoderności względem tożsamości osoby ludzkiej - człowiek projekt czy przypadek
}

\section{CONTEMPLATIVE FAITH IN THE TRIUNE MEETING IN BEING - AN ANSWER TO CONTEMPORARY POSTMODERN DILEMMA OF THE IDENTITY OF MAN (A PROJECT OR A COINCIDENCE?)}

In the context today's postmodernist undermining the identity of the human person, which determines the dramatic state of the Western-European intellectual culture (and humanities in general), the author weighs the question of man as a project or a coincidence. He refers to the Platonian concept of the world of shadows. In this context he discusses the question of man (a project? a coincidence?) who transcends the Nature (Physis) and, with the power of his spirit, ,",produces" the world which takes innumerable, new historical dimensions.

Key words: human oikoumene, West-European inteligibility, culture as a shadow of reality, Platonian world of, meaning of manhood, meaning of physis and oikoumene, objects of culture.

Chętnie zaryzykowalibyśmy tezę, że od czasu, kiedy myśl badawcza europejskiego kręgu kulturowego zaangażowała się w poznawcze poszukiwanie: ,jak?" względem physis rzeczywistości, stopniowo zatraciliśmy perspektywę dostrzegania całości rzeczywistości świata osób i rzeczy 
(w sensie starożytności greckiej). Zrozumiałe więc powinno okazywać się, że bliższe przypatrywanie się coraz bardziej dogłębnym szczegółom czy mikroszczegółom physis w coraz bardziej dzielących się i atomizujących dyscyplinach i subdyscyplinach nauki nie mogło zarazem nie pozbawić integralnego rozumienia, możliwego jedynie - jak uznajemy - w cierpliwym kontemplatywnym kształtowaniu w perspektywie spojrzenia na całość Physis - physis i zawartej w niej oikoumene. Wówczas nawet nieusuwalnie pojawiałoby się metodologiczno-badawcze pytanie, czy wystarczałby tenże ogląd; czy nie należałoby uwzględnić także kontemplatywnego „oglądu” „Rzeczywistości” - i to aż po sięganie [i sięgnięcie] ostatecznych przyczyn Physis i oikoumene. To zaś warunkowane pozostawało koncepcją nauki nowożytnej, która przecież ze swego projektu badawczego systematu wykluczyła metafizykę (w uproszczeniu), a w swej wielości wyspecjalizowanych dyscyplin z różnych gałęzi nauki (rozpoznawanej odtąd wyłącznie jako dziedzina i wiedza utylitarna) absolutyzowała się w niemożności komunikowania się. Nieosiągalnym więc stawał się badawczy interdyscyplinarny dyskurs.

Niestety wydaje się, że tak długo, jak nie zrozumiemy istoty uniwersytetu mediewalnego, wydani pozostaniemy mocy absurdalnego upowszechnienia pojęcia „kultury ogólnej” w sensie José Ortegi y Gasseta (1883-1955) - hiszpańskiego filozofa kultury i socjologa. Zasadnie zauważył on przecież, iż kultura może być wyłącznie ogólna, że np., nie jest się „kulturalnym” w fizyce lub matematyce, w chemii lub w biologii, gdyż w tychże dyscyplinach można pozostawać jedynie wykształconym, a w medycynie, prawie bądź inżynierii - wyspecjalizowanym. Należałoby mieć świadomość, że współczesne, ponowożytne uniwersytety stanowią jedynie skromne pozostałości i w pewnym sensie swoiste przeżytki tego, co w epoce niezwykle dogłębnego i twórczego fermentu społeczności łacińskiego Zachodu - mediewalnej Christianitas, stanowiło kształtowany w strukturze i społecznej potrzebie Uniwersytet (universitas magistrorum et scholarum). I chociaż uniwersytet mediewalny nie prowadził badań (w sensie specjalistycznych badań naukowych), to jednak wypełniony był wyłącznie „kulturą ogólną”. Właśnie wówczas - bardziej niż kiedykolwiek w dziejach przeszłości - bezsprzecznie pozostawał miejscem poszukiwania prawdy i jednoczesnego wykształcania systemu idei dotyczących świata (physis) i ludzkich oikoumene [ziemskiego Globu], jakie powinny skutecznie wyznaczać i jakie twórczo wyznaczały kierunek egzystencji chrześcijańskich społeczności europejskiego Zachodu.

Wydawać by się mogło, że powyższa kwestia przynależy do przeszłości i nie jest warta najmniejszej uwagi. Niestety, pozostaje tym 
bardziej aktualna, a nadto okazuje się zdecydowanie pilną do bardziej dogłębnego rozważania kwestią , do której imperatywnie należy badawczo powrócić, im bardziej rozpoznając współcześnie, że człowiek transcenduje Przyrodę i siłą swej istoty „,wytwarza świat”, przybierający niezliczone, wciąż nowe „oblicza” historyczne, jesteśmy w stanie w ramach uprawianej nauki różnie pojmować (resp. interpretować w kategoriach nauki) physis, Przyrodę: czy jako ogół rzeczy, czy jako ogół tego, co [zmysłowo] widzialne (resp. empirycznie postrzegalne), czy wreszcie jako całość bytu ${ }^{1}$.

Pozwolimy sobie powyższe zilustrować przykładem przywołania rozmaitych możliwości interpretacyjnych świata „cieni” Platona. Oczywiście na sposób klasyczny (w uproszczeniu) używa się określenia, że świat „cieni” nie jest prawdziwym światem, Rzeczywistością. Jest „cieniem” świata, właśnie dlatego ponieważ wyłącznie ten rzeczywisty jest „prawdziwy”; ale nie jesteśmy w stanie określić istoty tejże jego prawdziwości, gdyż scharakteryzowanie go jako „wydarzający” się mogłoby przeczyć jego istocie i podstawowej właściwości. Zauważmy nadto, że zamiast prawdziwy jako istotność tejże Rzeczywistości - „Świata” zwieńczonego wokół [Idei] Dobra i zwieńczonego w Dobru - co stanowi jedynie nasze zinterpretowanie Platońskiej Idei na użytek niniejszej refleksji, wystarczyłoby rozpoznać tenże świat jako ostateczny. Wówczas scharakteryzowanie prawdziwości nie byłoby wyłącznością rzeczywistości Idei-Dobra. I chociaż ona stanowiłaby ostateczność czy ostateczną rzeczywistość, to jednak ten świat, jaki jest tutaj i zarazem teraz - świat, który jest udziałem ludzkich oikoumene i udziałem każdego $\mathrm{z}$ nas $\mathrm{w}$ tychże oikoumene, okazywałby się równie prawdziwym wedle koncepcji Platona. Może nie chodziłoby o prawdziwość, ale o „rzeczywistość” wydarzania się czy stawania aż po - bliżej nieuchwytne - ,przyobleczenie” się w Ideę-Dobro.

Natomiast, skoro na samych sobie i tym, co stanowi nasz indywidualny i zarazem osobowy rozwój doświadczamy wydarzanie się physis „rzeczywistości”, to zarazem nie może nie być rozpoznawany tenże fakt stawania się czy wydarzania. W sumie świat „cieni” wyraża czy wręcz stanowi świat „kreacji” człowieczej. W taki sposób możemy zarówno interpretować sytuację ludzkich oikoumene, w których poszczególni i zarazem każdy z osobna - na miarę rozpoznania głębi swego ,jestestwa" - tworzy świat kultury i nadaje sobie aspekt człowieczeństwa. Jest to przecież także kreacja - i to w dosłownym rozumieniu świata „cieni” Platona. W innym jeszcze sensie kreacja w świecie „cieni” może z powodzeniem zostać zinterpretowana bądź

Por. R. Ingarden, Książeczka o człowieku, Kraków 1972, s. 13. 
rozpoznana, kiedy ludzkie oikoumene podejmują zmianę physis (resp. Przyrody), „ujarzmiając” ją (technika, rolnictwo, leśnictwo, energetyka itd.), i nadają jej rozmaitość sensów, których ona w sobie nie posiada, kiedy ludzkie oikoumene w ich poszczególnych osobach i podmiotach tworzą dzieła, różniące się w swej istocie w sposób istotnościowy od tego wszystkiego, co znajduje się w tymże świecie jako wytwór Natury, Przyrody, physis rzeczywistości.

Zauważmy, że wykształcone dzieła (w uproszczeniu) aż po inteligibilne opus okazują się wyrazem tożsamości kulturowej wykształconych mateczników cywilizacyjnych i zarazem dostosowane do ich kulturowego ducha, stanowiąc jakby dopełnienie tejże uporczywie kształtującej się tożsamości kulturowej ${ }^{2}$. I gdy okazują się już wytworzone - zazwyczaj na sposób materialny, gdyż ich zaistnienie na sposób duchowy wymaga ludzkiego działania bądź obecności, natrafia się na nie w świecie - jakby były czymś rzeczywistym. I niewątpliwie są czymś rzeczywistym, gdyż postrzegalne są na sposób empiryczny. Ludzkie oikoumene tworzą dzieła kultury i sztuki: muzykę, literaturę, malarstwo itd. Tworzą naukę, filozofię. Rozpoznają dzieje samych siebie - dzieje swej przeszłości i wszystkich ludzkich oikoumene w postrzeganiu globalnego świata. Są w stanie spojrzeć swemu ludzkiemu obliczu - bliżej nieokreślonej ludzkości, z perspektywy okołoziemskiej orbity. Nadto ludzkie oikoumene wytwarzają systematy swego zorganizowania - rodzinę i wszystkie inne rodziny, a następnie naród i wszystkie inne narody, co z kolei stawia je wobec imperatywu obowiązków - moralnej powinności tak samo wobec rodziny, jak i wobec narodu. Ale wykształcenie rodziny i narodu nie jest kresem ludzkich możliwości. Chociaż prymitywne zalążki tychże tworów możemy dość łatwo rozpoznać w świecie zwierząt, to jednak na nich przebiega wyraźna już granica. Bowiem wyłącznie ludzkie oikoumene ustanawiają wraz z instytucją małżeństwa i funkcją rodziny - i to jako ich logiczny ciąg: ojczyznę i systemy państw. Ludzkie życie nabiera coraz bardziej jakiegoś sensu i zarazem jakiegoś celu, którego by nie miało w całkiem pierwotnej i czystej Naturze, physis rzeczywistości; gdyby ludzkie istoty poprzestały na trudnieniu się zbieractwem i łowiectwem, gdyby grupy tychże przypadkowo trzymających się ludzi pozostały w jaskiniach. Tak, właśnie ten cały świat dziejowej przeszłości kształtujących się zalążków cywilizacyjnych mateczników pozostaje wyraźnym światem „,cieni”, który moc ludzkiej inteligibilności w interaktywnym - ale jedynie i wyłącznie w ramach wytworzonej kultury ludzkich oikoumene - i bezinteresownym trudzie poznania rzeczy niejawnych z Natury (resp.

Por. tamże, s. 14-15. Poniżej także nawiązujemy do sformułowań bądź parafrazujemy myśl Ingardena. 
physis rzeczywistości) jest w stanie odsłonić z tego ciągu wytwarzanych obliczy historycznych świata.

Zatem tenże [kulturowo] kreowany świat „cieni” (w sensie Platona) okazuje się w pełni całkiem odmiennym od Natury - i słusznie zauważa Ingarden, że może zajść okoliczność, iż poszczególny człowiek bądź ludzkie oikoumene prawie całkiem zapozna, że u podłoża tejże całej ludzkiej rzeczywistości kryje się Przyroda (resp. Natura), obojętna na wszelką wartość i nieczuła na wszelką dolę i niedolę bądź szczęście czy nieszczęście człowieka i ludzkich oikoumene. Bo rzeczywiście po wielkim wzlocie osiągnięć techniczno-technologicznych - od czasu niepowtórzonej w dziejach - rewolucji przemysłowej ${ }^{3}$ indoktrynowane resztkami formacji pozytywistyczno-materialistycznej ludzkie oikoumene współczesnych społeczeństw globalnych nie są w stanie dostrzec piękna fizycznego świata physis i sensu głębi wnętrza Wszechświata, uprzystępnianego osiągnięciami nauk astronomicznych. Paradoksalnie, nie są w stanie postawić na nowo pytania o sens i cel rzeczywistości, która stała się ich [kulturowym] wytworem i zarazem materialnym (funkcjonalno i techniczno-technologicznym) udziałem. Zdają się powracać do stanów bardziej pierwotnych, bardziej prymitywnych - delektują się jedzeniem bez konsekwencji przybrania na wadze, na długie godziny rozsiadają się wygodnie w fotelach przed audiowizualnym sprzętem bez potrzeby fizycznego wysiłku tworzenia czegokolwiek z siebie samych, konsumując medialne info i newsy sądzą „rozumieć” wszystko i wszystkich, pozbawieni lęku o cokolwiek w wyniku zabezpieczenia się przed przypadkowym spłodzeniem potomstwa „,bawią” się własną seksualnością itd. Ale, czy faktycznie stan, jaki pozostaje ich udziałem, jest powrotem do Natury, physis? Nie wykazują już umiejętności otwarcia się na coś nieokreślonego, niewyrażalnego słowami, wyrażeniami. Zdają się nie być w stanie przeżyć autentycznej radości bądź bezinteresownie zająć się poznaniem czegoś, co wykracza poza ich pozytywistyczny świat zmysłowych doznań. Taki oto wydaje się pozostawać świat społeczeństw konsumpcyjnych, w którym tworzą się nieokreślone establishmenty usiłujące nim zarządzać. Pragną zwrotnie kreować ,światem” wytworzonym. Wyznaczać wszelkie standardy - od wyznaczania stopnia poziomu

3 Dla uprzytomnienia skali zmian warunków życia, dokonanych przez nowożytną rewolucję techniczną (z około połowy XVIII stulecia) przyrównuje się (Kenneth Boulding) życie ludzi z połowy XVII i rozpoznaje, że było ono bardziej podobne do bytu wcześniejszych o cztery tysiąclecia od nich mieszkańców Sumeru czy starożytnego Egiptu aniżeli do stulecia trzy wieki późniejszego, czyli do teraźniejszości XX i XXI wieku. Nowożytna rewolucja przemysłowa spowodowała, że współczesne (od dwóch stuleci) pokolenia żyją w warunkach techniki wyraźnie doskonalszej. 
intelektualnego nowych pokolen ${ }^{4}$ do zarządzania moralnością czy - aż nie do wyobrażenia w ostatecznych skutkach - wręcz wyznaczania katalogów norm moralnych i kryterium sumienia. I tutaj właśnie się pojawia dylemat, dotyczący tożsamości osoby ludzkiej: człowiek projekt czy przypadek. Bo faktycznie na tak nadbudowywanym świecie „,cieni” na innym, kulturowo wytworzonym juź świecie „cieni” (w sensie kategorii Platona), zaczynają się rozmywać właściwe kategorie rozumienia: co jest rzeczywiście „cieniem” rzeczywistości physis, Przyrody, Natury, a co stanowi już [absolutne] zaprzeczenie tego czysto intencjonalnego tworu czy duchowo-materialnych tworów. Należy bowiem rozpoznać, że rzeczywistość kulturowego świata „cieni” nosi w sobie tylko pozór istnienia, który naznacza, znamionuje i zarazem charakteryzuje wszelkie duchowe dzieła człowieka - jak dzieła sztuki (aż po wytwory architektury) i rozmaite wytwory kultury ludzkich oikoumene - i to bez względu na fakt, czy stanowią opus poszczególnej osoby, czy też całych społeczeństw jako podmiotów twórczych ${ }^{5}$.

Ale współczesność postmodernistyczna najpewniej nie rozumie, że przypadkowość ludzkiej istoty i zarazem ludzkich oikoumene można postrzegać w różnych wymiarach i inteligibilnie rozpoznawać na różnych płaszczyznach. Współczesne manipulowanie ludzką seksualnością i płciowością oraz [m.in.] współczesne pragnienia konsumpcyjne wytworzyły przekonanie o możliwej i dowolnej kreacji człowieka, będącego ziszczeniem żądzy posiadania ze strony dawców biologicznego materiału dla in vitro (w uproszczeniu). Medyczna technika in vitro - technika, o której skutkach sprawczych „kreowania” nie sposób niczego jeszcze rozstrzygnąć: co przyniesie w konsekwencjach „wyprodukowanych" istot ludzkich, zdaje się sprawiać wrażenie, że [konkretny] człowiek (resp. poczęte życie, człowieczy płód w łonie kobiecym, matczynym) może jednak być „przypadkiem”, balastem dla rodziców społeczeństwa konsumpcyjnego - balastem [konsumpcyjnego] „bawienia” się [swą, czyjąś] seksualnością, płciowością.

Lecz zauważmy nadto - w postmodernizmie, jaki konceptualnie wychwytujemy i zarazem inteligibilnie wykształcamy - także w sensie tworu czysto intencjonalnego, człowiek może również być [rozpoznanym] projektem; może być uznany jako projekt - na tej samej zasadzie, co ludzkie istoty $\mathrm{z}$ in vitro i ludzkie istoty, poczęte w głębiach misterium

$4 \quad$ Czyli, m.in.: konsekwencje zaangażowania współczesnej edukacji w kształtowanie rozwoju umysłowego dzieci i młodzieży za pomocą wiedzy nieprzedmiotowej, kształtowania ich poziomu intelektualnego w oparciu o wiedzę niepoznawczą itd.

Por. R. Ingarden, Książeczka o człowieku..., dz. cyt., s. 17. 
stworzenia, głębi interpersonalnej miłości stwórczej, jaką wyraża w akcie [twórczej, udzielającej się, osobowej] miłości kobieta i mężczyzna. Jest więc on projektem „nowego” społeczeństwa, „szczęśliwej ludzkości”, „nowej” ludzkości. Niestety, nie będziemy szerzej rozwijać tego wątku nadbudowy ideologicznej - swoistego nadbudowania na tymże świecie „cieni” - w sensie „cienia” rzeczywistości, jaką stanowią wytworzone przez człowieka i ludzkie oikoumene twory kultury i wszelkie opus duchowe. Jest to w pewnym sensie dalsza konsekwencja konstrukcji filozoficznej Kartezjusza: podmiotowego „Ja” i świata nie-,,Ja”, czyli innej jeszcze konstrukcji intencjonalnej - konstrukcji, która - w pewnym sensie na sposób zdeterminowany - wyznaczyła losy społeczności i społeczeństw europejskiej nowożytności. Ale zauważmy, że nie byłoby możliwe (w sensie ewentualności, przypadkowości) wykształcenie przez autora Umowy społecznej i Rozprawy o pochodzeniu i podstawach nierówności między ludźmi swych idei natury człowieka jako tabula rasa i pierwotnego człowieka jako „dobrego dzikusa”, jako jeszcze nieucywilizowanego dobrego człowieka, czyli nieskażonego złem określonych społecznych warunków - idei, która okazała się inspirującą i przesądzającą o podjęciu czynu rewolucyjnego przez jakobińskich przywódców rewolucji francuskiej ${ }^{6}$, gdyby uprzednio - w schyłkowości mediewalnej Christianitas - nie dokonało się pewne, wydające się marginalnym, akcydentalnym, przewartościowanie w rozumieniu rzeczywistości świata osób i rzeczy. Otóż współczesne badania [źródłowe i inne] wykazują ${ }^{7}$ że myśl teologiczna renesansu stuleci XII i XIII - owej dojrzałej pełni średniowiecznej - doznała niewątpliwego skrzywienia w [nowożytnym] Renesansie i Humanizmie [wieku XVI] - dobie głębokiego pęknięcia w ciągłości kultury łacińskiego Zachodu ${ }^{8}$, kiedy wielu autorów-teologów, będąc pod wpływem [tzw.] sztywnego arystotelizmu, nie tylko głosiło hipotetyczną możliwość „stanu czystej natury”, ale uważało wręcz za zasadne, iż wszelka

$6 \quad$ Dopowiedzmy. Myślenie jakobińskich przywódców antyfeudalnego zwrotu naznaczył piętnem sylogizm ideologicznych zdań-przesłanek, zdający się przekonywać, że jeśli w zasadzie człowiek rodzi się dobry i nieukształtowany [bądź nie w pełni uformowany w swych psychofizycznych władzach], to możliwe jest pełne jego przystosowanie do wizji „nowego” społeczeństwa, jakie zamierza się wytworzyć według bliżej nieokreślonego wzorca - utopijnie doskonałego. Oczywiście wiemy, że ów mit o pierwotnie dobrej i całkowicie modyfikowalnej naturze człowieka pozostał aż po współczesność początków XXIstulecia obecny w dyskusjach na temat historii i psychologii człowieka.

Zob. H. de Lubac, Surnaturel, Paris 1946.

Dopowiedzmy - pęknięcia, spowodowanego przemożnym wpływem hellenistycznej wersji orientalnej kultury greckiej w tym, co historycznie określone i zarazem wyznaczone zostało upadkiem Bizancjum w 1453 r. i jego cezurą. 
refleksja o człowieku i jego przeznaczeniu powinna się urzeczywistniać przy uwzględnieniu takiegoż punktu wyjścia i zarazem nieustannego odwoływania się do takiegoż kryterium, czyli „stanu czystej natury”. I faktycznie Platoński świat „cieni” w intelektualnym opus Rousseau „rozpoczyna” się poza granicą czy granicami biblijnego Raju.

Dopowiedzmy - wobec takiej sytuacji badawczej w sensie wiedzy o błędnych stanowiskach intelektualnych, jaka jest udziałem współczesnej nauki - także i przede wszystkim nauki teologicznej, należałoby konsekwentnie zawrócić z perspektywy nakreślonej przez autora Umowy społecznej jako pewnego podglebia (resp. podłoża) zaczątków formacji empirycznej i materialistyczno-pozytywistycznej oraz rzetelnie podjąć próbę skorygowania skutków nieszczęśnie wdrożonych i nieszczęśnie odwzorowanych w praxis wydarzania się społeczeństw zachodnioeuropejskich - wdrażania idei społeczno-politycznych Rousseau i jego nowożytno-ponowożytnych sukcesorów.

Powróćmy jeszcze do społeczeństw - ludzkich oikoumene, których - jak podnieśliśmy powyżej - kulturowe twory noszą wyłącznie pozór istnienia. Zwróćmy uwagę na zadziwiające zjawiska zdolności niektórych z tychże etnicznych oikoumene ludzkich czy wręcz skłonności do empiryzmu i pozytywizmu. Zasadne byłoby postawienie badawczego pytania: czy jest to nieprzezwyciężalna przypadłość wrodzona im, czy może nabyta, czy też całkowicie stanowiąca wewnętrzność tychże anglosaskich etniczności; właśnie bowiem wychwytujemy współcześnie - bardziej niż kiedykolwiek w dziejach przeszłości, że język Bacona, Locke'a, Hobbesa, Benthama i Darwina okazując się najdoskonalszym instrumentarium (resp. środkiem wyrazu) zachodniego empiryzmu, a ostatnio także materializmu i konsumpcjonizmu, nie jest w stanie wyartykułować innych treści niż pozytywistycznej (resp. świeckiej w sensie oświeceniowości) ideologii ekspansjonistycznej bądź treści czysto empiryczne ${ }^{10}$. Nie zna wyrażeń niepozytywistycznych. Nie wykształcił pojęć wyrażających transcendentność, transcendencję itp.

Oczywiście wielce interesujące może okazać się zagadnienie, jak rzecz ta - owe niezwykłe przedsięwzięcie się ma do faktu, że kondycji mentalno-kulturowej ludów celtycko-germańskich - faktycznie odmiennej od starożytnych basenu śródziemnomorskiego czy, chociażby, istotnie różnych od azjatyckiego matecznika cywilizacyjnego, udało się osiągnąć tak niezwykły zwrot funkcjonalno-pragmatyczny

9

Por. J. I. Saranyana, J. L. Illianes, Historia teologii, tłum. P. Rak, Kraków 1997, S. $448-449$.

10

Por. H. Skolimowski, Filozofia żyjaca. Eko-filozofia jako drzewo życia, tłum. J. Wojciechowski, Warszawa 1993, s. 145. 
w odniesieniu do tychże samych „wynalazków”, którymi równie i przede wszystkim na długo wcześniej posługiwano się w Azji bądź w greckiej i arabskiej strefie Morza Śródziemnego ${ }^{11}$ - zwrot, skutkujący zmianą metod pracy i zarazem wzrostem jej efektywności. Jednak, z pewnością kwestia powyższa pozostanie niestety retorycznym pytaniem. Wydaje się bowiem, że współczesne społeczeństwa dawnego, pofrankijskiego Zachodu nie wydają się rozumieć wszystkich wyższych pojęć, dotyczących człowieczeństwa, honoru, suwerenności, wolności duchowej, moralnej i obywatelskiej itd. Współczesne face à face dominujących systematów państwowych i ich społeczeństw zachodnioeuropejskich i obecnego systemu państwowego Rosji w sprawie Ukrainy - wraz z dość poważnym zagrożeniem dla stabilności kulturowej i gospodarczo-politycznej Europy - dość wyraźnie wykazuje, że pozostają dla nich bez znaczenia ponadempiryczne i pozytywistyczne wartości oraz postawy moralne - takie, jak honor, bezinteresowne poświęcenie własnego życia dla drugiego ${ }^{12}$, poświęcenie zysku ekonomicznego dla wyższych wartości, jak suwerenność innego narodu, społeczeństwa itd.

$11 \quad$ Przyjmuje się, że wynalazek podkowy końskiej stanowił tryumf średniowiecznego rolnictwa (por. R. Fossier, Ludzie średniowiecza [Ces gens du Moyen Âge], tłum. A. Czupa, Kraków 2009, s. 204-206). Umożliwiał on głębszą orkę ciężkiej gleby, co było niewykonalne za pomocą prostego lemiesza doby np. merowińskiej Galii. W dziedzinie rolniczej ów wynalazek dopełniły także inne niemniej przełomowe rozwiązania: podkowy dla konia i innych zwierząt pociągowych, zaprzęganie z zakładaniem chomąta na kark lub jarzma czołowego w zależności od rodzaju zwierzęcia. Jednak najbardziej interesującym wydaje się sposób w znaczeniu dosłownym i intelektualnym - wnikania do zachodniej Europy ducha owych pomysłów, ajeszcze ważniejsze wykształcania idei ich praktycznych zastosowań, którego - jak się okazuje - pozbawieni byli najpewniej starożytni, uchodzący dotąd za bardzo kreatywnych. Wobec faktu, że znajomość wielu z tych „wynalazków” potwierdzono w Azji bądź w greckiej i arabskiej strefie Morza Śródziemnego w bardziej prymitywnej formie wraz z nierównomiernym rozprzestrzenieniem tych cywilizacyjnych usprawnień i nowości - bowiem do końca XVI stulecia (w uproszczeniu) używano w Europie łopat, motyk, grac i wideł także na wielkich powierzchniach, co nie przyczyniało się do większej skuteczności niż na wsiach w Azji - zasadniczy zwrot mógł być spowodowany kondycją mentalno-kulturową ludów celtycko-germańskich - odmienną od starożytnych basenu śródziemnomorskiego czy, chociażby, azjatyckiego matecznika cywilizacyjnego.Zatem, czyżby pierwszorzędna rola przypadała cesze empirycznej obserwacji uprawiającego ziemię chłopa kręgu kultury celtyckogermańskiej i ludzi przymuszonych do zmiany metod pracy w celu zwiększenia produktywności w miarę rozprzestrzeniania się terenów uprawnych i rosnących ich potrzeb żywnościowych?

12 W tejże kategorii należy postrzegać wolę czy wręcz żądzę aborcji [dziecka nienarodzonego] współczesnych Europejek (w uproszczeniu) ze społeczeństw konsumpcyjnych Zachodu. 
Niewątpliwie jest to cały fałszywy ideologicznie świat „cieni” nadbudowany na tym, który wszelkim kulturowym wytworom człowieka w jego interakcji z ludzkim oikoumene przydaje znaczenie czy charakterystykę pozoru istnienia. Wydaje się więc, że próba rozstrzygnięcia kwestii tożsamości osoby ludzkiej: człowieka jako projektu czy jako [ewolucyjnego] przypadku, wzniesie jedynie jeszcze jeden krąg w tej konstrukcji pozorności świata „cieni”, nie rozstrzygając w istocie niczego. Rozważanie bowiem, na ile kulturowo-konsumpcyjny człowiek jest wytworem kulturowym wprowadza wyłącznie w pułapkę pozorności wszystko to, co dotychczas uznane zostało jako wartość i stało się wytworem człowieczeństwa w sensie (dziedzictwa materialno-duchowego) spełnienia się w ,jestestwie” poszczególnego człowieczego podmiotu, osoby. Nadto deprecjonuje człowieka jako twórcę wartości, jednocześnie kwestionując cały dotychczasowy świat kultury - świat w sensie rzeczywistości przetworzonej, istotnie różnej od Przyrody jako „nagiego” żywiołu w świecie [kulturowym] otaczającym człowieka i każde cywilizacyjne (kulturowo-religijne) ludzkie oikoumene.

Powyżej wyraziliśmy badawcze przekonanie, że współczesność postmodernistyczna najpewniej nie jest w stanie inteligibilnie uchwycić czy wręcz nie rozumie, iż przypadkowość ludzkiej istoty i zarazem ludzkich oikoumene można postrzegać w różnych wymiarach i inteligibilnie rozpoznawać na rozmaitych płaszczyznach. Rozpatrzyliśmy więc ją w kontekście ludzkich zachowań, działań. Do pełnego badawczego obrazu czy inteligibilnego rozumienia należy rozważyć kwestię tożsamości osoby ludzkiej - człowieka projektu czy przypadku - w sensie bardzo szerokiej perspektywy physis rzeczywistości (resp. Natury, Przyrody).

Bardzo interesująca wydaje się koncepcja [tzw. eko-filozofii] Henryka Skolimowskiego, postulująca ponowne odkrycie sensu człowieczeństwa odniesionego do sensu Wszechświata, bowiem w dotychczasowym, nowożytnym badaniu świata fizycznego zostały stworzone skomplikowane [inteligibilne] matryce tak subtelne, zawiłe i szczegółowe, że przesłoniły zrozumienie czegoś tak aksjologicznie różnego od empiryczności, jak sens życia ludzkiego ${ }^{13}$. Lecz najbardziej niezwykłe, co w tymże filozoficznym postulacie można uchwycić, dotyczy przede wszystkim wadliwego kodu odczytywania i konsekwentnie rozumienia natury. Skolimowski postuluje „opracowanie” nowej metafizyki, która wyczerpywałaby się na nowym odczytaniu Kosmosu, procesu ewolucji i natury ludzkiej jako części tego samego kontekstu ${ }^{14}$. Ale najbardziej nieoczekiwanym rezultatem (w pewnym sensie konsekwencją

13 Por. H. Skolimowski, Filozofia..., dz. cyt., s. 11. 
współczesnego odkrycia [tzw.] stałych kosmologicznych, które z kolei są „odpowiedzialne” za strukturę Wszechświata i jego niepowtarzalne wzorce ${ }^{15}$ - i zarazem stwierdzeniem twórczego oglądu rzeczywistości wydarzającego się Wszechświata, nakazującego postawić kilka twórczych pytań, a spośród nich kwestię: dlaczego Wszechświat jest taki, jaki jest) wydała się niemal wstrząsająca podstawami nowożytnych formacji pozytywistyczno-empirycznych konkluzja, że układ Wszechświata jest tak doskonale zrównoważony, iż życie na ziemskim Globie jest nie tylko możliwe, ale najpewniej wręcz konieczne. Wiemy, że odkrycie tychże niezwykłych parametrów Wszechświata doprowadziło do sformułowania zasady antropicznej, wyrażającej interaktywną relację pomiędzy Kosmosem a ludzkim oikoumene, stwierdzającą, że los Wszechświata jest związany z losem człowieka (antropos) ${ }^{16}$.

Można by postulat metodologiczny Skolimowskiego, sprowadzić do tego, co pozostawało zapoznanym odkryciem starożytnych Hellenów - Jończyków, którzy w physis rzeczywistości uporządkowanej (Kosmos), rozróżnili i zarazem wyróżnili z owej physis, osadzoną w niej [ludzką] oikoumene z racji tego, czym owa oikoumene pozostaje, będąc $\mathrm{w}$ stanie postawić pytanie o sens tegoż physis jako Physis, Universum. Retoryczne jest pytanie, jak wyglądałyby poszczególne etapy rozwoju myśli filozoficznej i zarazem rozwój kulturowy ludzkich oikoumene europejskiego kręgu cywilizacyjnego, gdyby - zwłaszcza u schyłku mediewalnej Christianitas - nie zapoznano imperatywnego postula$\mathrm{tu}$, że physis należy badać w funkcji oikoumene - gdyby pamiętano, że konsekwentnie do rozpoznania niezwykłości ludzkiej oikoumene wykluczone jest nie tylko każdorazowe „manipulowanie” bądź przedmiotowe (resp. instrumentalne) traktowanie ludzkich oikoumene, ale także bezwzględne - i niekiedy wręcz brutalne - posługiwanie się uzyskanymi rezultatami badawczymi nad ludzką psychofizyczną istotą i ludzkim oikoumene w perspektywie naukotwórczego pytania: ,jak?” (hoti? quia?) - jak działa? Jak funkcjonuje w zamiarze skutecznego ubezwłasnowolnienia: intelektualnego i kulturowego, osobowościowego i duchowego.

Najpewniej nowożytne przedsięwzięcie coraz bardziej wyłącznego koncentrowania się na naukotwórczym pytaniu: ,jak?” (hoti? quia?) $\mathrm{w}$ odniesieniu do physis jako takiej - przy zaniedbaniu podstawowej [naukotwórczo] sformułowanej przez Greków kwestii: „dla-czego?”

$15 \quad$ Zob. F. Dyson, Disturbing the Universe, 1981.

16 Por. H. Skolimowski, Filozofia..., dz. cyt., s. 25. 
(diá ti? propter quid? ${ }^{17}$, nie wygenerowałoby takiego stanu dowolnej, kreatywnej ingerencji w ludzkie życie i nie przyczyniłoby się do zapoczątkowania kreowania wręcz człekokształtnych hybryd, gdyby w swym europejskim (resp. zachodnioeuropejskim) rozwoju nauka (jako konsekwentne rozwinięcie filozofii w klasycznej koncepcje starożytności) nie zapoznała w swych przedstawicielach (bądź też jak się wydaje - lekceważąco nie pominęła lub nie doceniła) istotnej ważności wyróżnionej oikoumene z physis - oikoumene, której poszczególne indywidua (antropos) zdolne są w sprawności „mądrości rozumu" (oczywiście - cierpliwie i zarazem dogłębniej rozwijanej) do bezinteresownego „oglądu rzeczywistości”, kontemplacji sięgającej ostatecznych przyczyn physis i ludzkiego zaistnienia w niej.

Wydaje się zatem całkiem zasadne przekonanie, iż nieposkromione kreatywne żądze uprawiających nauki przyrodnicze skutecznie powstrzymywałyby moralnie destrukcyjne zakusy, gdyby owa nauka, czyniąca „wgląd” w „mechanizm” czy biochemiczno-psychofizyczne „funkcjonowanie”: „jak działa physis”, była uprawiana i badawczo rozwijana w funkcji oikoumene, wyróżnionej z physis.

I oto w naszym rozważaniu zakreśliliśmy powrót do punktu wyjścia refleksji. Wyraziliśmy bowiem na wstępie niniejszych rozważań przekonanie, że najprawdopodobniej odmiennie potoczyłyby się nowożytne dzieje europejskiego kręgu kulturowego, gdyby wskutek złożonych okoliczności myśl badawcza nie zaangażowała się w poznawcze poszukiwanie: ,jak?” względem physis rzeczywistości, które decydująco przyczyniło się do utraty perspektywy integralnego rozumienia physis rzeczywistości, aż po kontemplatywne „sięganie” do ostatecznych przyczyn rzeczywistości świata osób i rzeczy (w sensie starożytności greckiej). Być może nawet należałoby rozważyć, na ile wytworzony kulturowy „cień” rzeczywistości nowożytności europejskiej byłby mniej szkodliwy - kulturze wysokiej inteligibilności [teoretycznej, kontemplatywnej], gdyby zamiast w anglosaskich oikoumene, był wykształcany w oikoumene posługującej się językiem polskim - kulturowymi wyrażeniami języka, który zachował słowiańską duszę, pomimo że kształtował się pod przemożnym wpływem łaciny ${ }^{18}$.

Powyższe należy rozumieć w dość szczególnym sensie. Wiemy bowiem, że zanim starożytni Jończycy postawili kwestię krytycznego zrozumienia rzeczywistości świata osób (oikoumene) i rzeczy (physis) - kwestię bezinteresownego poznania rzeczy niejawnych z natury,

17 Por. M. A. Krąpiec, Przedsłowie, [w:] P. Jaroszyński, Człowiek i nauka, Lublin 2008, s. 5-7. 
w ideale bezinteresowności została uprzednio wykształcona mowa i sztuka pojęciowego myślenia. I wydaje się nieprzekonywującym, aby na tym miały się wyczerpywać kategorie wzrastającej bezinteresowności w odniesieniu do ludzkiej oikoumene. Mamy na myśli bezinteresowność dzielności moralnej i heroiczność bezinteresownego poświęcenia aż po ofiarę z własnego życia, jaka stała się udziałem polskiej kulturowej oikoumene w jej dziejach - jako niezwykłego i niepowtarzalnego fenomenu Rzeczypospolitej. Czy którakolwiek z zachodnioeuropejskich oikoumene aż po ich współczesne społeczeństwa konsumpcyjne jest w stanie zrozumieć treść duchową i moralną, zawartą w idei gloria victis, która - paradoksalnie - poszerzyła perspektywę bezinteresowności: mowy, sztuki pojęciowego myślenia, poznania rzeczywistości physis i heroicznego czynu - ofiary ze swego życia w darze innym, swej ojczyźnianej wspólnocie?

Wydaje się więc, że twory kultury i wszelkie cywilizacje, wytworzone przez człowieka, nie wydają się wyczerpywać na tymże kreowanym świecie mowy, umiejętności pojęciowego myślenia - i to jedynie w niektórych spośród siebie, które pojawiły się w rozciągłości dziejów: w dziejowej przeszłości - oraz poznania ostatecznych przyczyn rzeczywistości physis i ludzkich oikoumene. Oto bowiem człowiek i ludzka oikoumene w określonej kulturowości - czyli polskiej cywilizacji - jest w stanie przewyższyć wszelkie ideały i najszlachetniejsze - moralne nawet $\mathrm{w}$ postawie dokonanego na nim przez agresora unicestwienia, osiągając niedostępny - dla wszystkich innych „,adoratorów [bożka]” zmysłowości: obfitego jadła, cielesnej rozkoszy i wygody - szczyt dojrzałości moralnej: gloria victis ${ }^{19}$. Postawę niezrozumiałą dla globalnych społeczeństw konsumpcji, pozostających z pewnością osławionymi „marionetkami” władzy współczesnego świata „cieni”.

Tymże tworem kultury - „cienia” rzeczywistości physis świata osób i rzeczy, zbliżyliśmy się do ostatniego, najwyższego poziomu ludzkiego oikoumene, jakie jest jego udziałem w przekraczaniu fizykalnej (fizykalno-biologicznej) granicy Przyrody, Natury. Człowiek bowiem może w swej kontemplatywności - głębi kontemplatywnej (resp. mądrości

19 Podnosimy kwestię, która na przekór domniemaniom wizjonerów fragmentyczności[widzenia świata](np. formacji empiryczno-pozytywistycznej) uświadamia, że żyjemy glorią życia (glorią istnienia) - mężnym spełnianiem się w ,,jestestwie”, niekiedy także heroicznym w złożeniu ofiary ze swego życia w imię prawdy moralnej, ,transcendentnej” (w uproszczeniu) w odpowiedzialności za moralne dobro ludzkich pokoleń, w poczuciu honoru, odpowiedzialności, dumy, troski o sprawy wielkie itd. 
teoretycznej ${ }^{20}$ ) sięgnąć aż ostatecznych przyczyn Rzeczywistości ludzkich oikoumene w physis rzeczywistości [Kosmosu]. Ale ludzka możność sięgnięcia aż w taką głębię - uzyskania styczności z czymś, co mu się wydaje czymś większym i doskonalszym niż on sam oraz niż wszystkie ludzkie oikoumene i co przewyższa wszelkie idee i najszlachetniejsze ludzkie ideały, a także wszelkie doskonałości bytu skończonego w ogóle ${ }^{21}$ - dowodzi przede wszystkim możności uzyskania „styczności” z „Samoistnym” Istnieniem, Prawdą istniejącą samoistnie $-\mathrm{z}$ dającym się rozpoznać [(resp. udzielającym się $\mathrm{w}$ darze

$\mathrm{Na}$ badawczą uwagę zasługuje grecki termin 'theoría'. Przypomnijmy - termin 'theoria' wyraża jedną z zasadniczych cech myśli starożytnej, jeśli nie jej cechę najbardziej typową; z perspektywy dziejów dostrzeżono, jak z postawy poznawczej i moralnej człowieka ulega transformacji w moc (resp. energię) bytotwórczą w neoplatonizmie (zob. G. Reale, Historia filozofii starożytnej. I. Od początków do Sokratesa, tłum. E. I. Zieliński, t. 1, Lublin 1994, s. 469-498). Chodzi o hojne głębią intelektualną myślenie (namysł nad Rzeczywistością, metamyślenie), osiągane wyłącznie w bezinteresownym trudzie poznania rzeczy stanowiących [nieempiryczną, a przyczynową w sensie theoria Arystotelesa] istotnościową [w sensie eidos starożytnych] głębię wydarzającej się rzeczywistości. Równie inteligibilnie niezauważone zdaje się pozostawać rozumiejące oglądanie rzeczywistości. A przecież stanowi jako postawa poznawcza najwyższy przejaw życia w możności kontemplatywnego oglądu physis rzeczywistości: gnónai kai theorésai. W konsekwencji życie ludzkie pozbawione bios theōrētikos traci swój najgłębszy sens - także w znaczeniu ,ponad-człowieczej”(resp. zdolności) „mocy” w człowieku jako możliwości sformułowania intuicyjnego zapytania o zasadę, przyczyny i elementy physis [jako całość] wraz z kierowaniem inteligibilnego zainteresowania racjonalną odpowiedzią jako pozostającej udziałem jej Stworzyciela, będącego Pierwszą „Przyczyną” (w sensie Arystotelesa) jej zaistnienia, bytowania itd. Dopowiedzmy nadto-jest zrozumiałe, że inspirując się zasadnym spostrzeżeniem niemieckiego uczonego (filologa) Ulricha von Wilamowitz-Moellendorffa(1848-1931) - twórcy metody historycznej w filologii klasycznej, iż greckie słowo: theos (opisujące boga Platona), występuje zasadniczo w funkcji predykatywnej, powinniśmy konsekwentnie przepracować dotychczasowe stanowiska intelektualne, które wyznaczyły i zarazem wyznaczały dotychczasowe osadzenia intelektualne dla ustalania bądź kształtowania bardziej ogólnych tendencji dla wszystkich dyscyplin szczegółowych. W kwestii powyżej przywołanych ustaleń Wilamowitza, pozwalających rozpoznać, iż w odróżnieniu od chrześcijan Grecy nie stwierdzali istnienia Boga, aby konsekwentnie, jak ci pierwsi, w dalszym etapie refleksji intelektualnej dążyć do ustalenia atrybutów tejże Istoty boskiej - powinniśmy wyciągnąć wszystkie konsekwencje tego badawczego odkrycia. Zatem, czy nie powinna zostać przywrócona i zarazem należycie uwydatniona korelacja pomiędzy ludzką sprawnością theoria a theos, rozumianymi jako każde zjawisko ponadludzkie, wieczne (w sensie nieprzemijania, nie ustawania), każdej mocy postrzeganej w zewnętrzności i wewnętrzności (w uproszczeniu) physis, która nie okazuje się być zrodzona wraz z człowiekiem i nie wyczerpuje się, nie znika czy nie odchodzi wraz z nim bądź ludzkimi oikoumene? (por. G. M. A. Grube, Plato's Thought, Methuen 1935, s. 150).

Por. R. Ingarden, Ksiażeczka o człowieku..., dz. cyt., s. 16. 
swej udzielającej miłości) w Słowie objawiającym i zarazem „dającym” zrozumieć aż pełnię udzielenia i w pełni tego udzielenia w „Wydarzeniu" Jezus-Chrystus] Stworzycielem tejże Rzeczywistości, której ostatecznych przyczyn jest osoba ludzka w stanie dosięgnąć. Czy jest więc projektem, czy też przypadkiem?

W tymże wymiarze nie sposób nie dostrzegać ludzkiego podmiotu i ludzkiej osoby wraz z ludzkimi oikoumene [w ich zdolności do przekraczania „granic” Przyrody (resp. Natury)] wyłącznie i jedynie jako projektu Stwórcy, Stworzyciela tejże Rzeczywistości, której kosmiczną głębię dosięgamy posiadaną racjonalnością (w sensie Arystotelesowego poznania zmysłowo-rozumowego) w najodleglejszych zakątkach astronomicznego Wszechświata - tak, jak [w niektórych spośród nas] w bezinteresownym „oglądzie” rzeczywistości dosięgamy głębi ostatecznych przyczyn tejże physis osób i rzeczy. Nie jest więc człowiek przypadkiem bądź przypadkowym stworzeniem w całym tymże Opus sprawczym jego Stworzyciela, jego Pierwszej (resp. Najpierwszej) Przyczyny (w sensie Arystotelesa i Akwinaty).

Tak przynajmniej postrzega się ludzką osobę i ludzki podmiot spełniający się w swym ,jestestwie”, jakie zostało mu udzielone, z tejże wysokiej (resp. uwewnętrznionej mądrości teoretycznej, mądrości rozumu) perspektywy rozumności, jaka z kolei nie musi pozostawać udziałem licznych ludzkich oikoumene wraz z ich ludzkimi podmiotami - oikoumene zagubionych i zarazem gubiących się w tworzeniu złudnych kolejnych warstw świata „cieni”, światów „,cieni”.

Ale nie można zakończyć na tym ciągu wyrażonej w tymże rozważaniu myśli. Myśl nie byłaby integralną całością, gdyby nie zostało przez nas wyrażone to, co uchwytne jest człowieczą inteligibilnością pomiędzy dosięgalną „głębią" racjonalnego oglądu astronomicznego Wszechświata i „głębią" kontemplatywną osiągania „wejrzenia” w ostateczne przyczyny physis świata osób i rzeczy. Właśnie w tym wymiarze uzyskamy - jak badawczo oczekujemy - pełne i zarazem ostateczne rozstrzygnięcie postawionego [współczesnym postmodernizmem] dylematu tożsamości osoby ludzkiej: ludzkiego projektu czy przypadku. Nie sposób bowiem nie zwieńczyć powyższych rozważań nad charakterem czy znamieniem ludzkich oikoumene refleksją nad „Wydarzeniem” Jezus-Chrystus.

Właśnie stawia ono podobne retoryczne zapytanie - dylemat projektu czy przypadkowości. Dylemat ów można wyrazić na liczne sposoby. Myśl badawcza (religioznawcza) oraz myśl teologiczna i filozoficzna (filozofii religii) podjęła kwestię i na sposób wycinkowości kształtowanych dyscyplin, w które wtłoczyła zagadnienie, próbowała uzyskać 
zadowalającą odpowiedź. Ale ona naznaczona pozostawała inteligibilną wycinkowością. Dlatego należy ją badawczo sformułować i zarazem postawić w kontekście tego, co powyżej rozważyliśmy.

Sformułujmy zatem kwestię tego dylematu: czy chrześcijaństwo jest jedną z wielu przypadkowych dróg religijnego spełnienia się człowieczego podmiotu, czy darem Stworzyciela udzielonym ludzkim oikoumene - tak, jak udzielona została im możność spełniania się w ,jestestwie”. Oczywiście, można by ją wyrazić wszelkimi innymi wyrażeniami, jakie już postawiono.

Znamienne jest jednak, że spośród wszystkich „,ścieżek” i „dróg” religijnych i kulturowo-religijnych tradycji, jakie bezsprzecznie z wewnętrznego imperatywu doświadczenia bytu ludzkie oikoumene wykształciły w swych kulturowych dziejach, jedynie chrześcijaństwo - a w nim [rozpołowionym na obrządki i wyznania] wyłącznie katolicyzm sięgnął po najwyższe kontemplatywne zdolności inteligibilne, aby zrozumieć i rozczytać sens objawiającego się Słowa w stworzeniu wraz z jego ześrodkowaniem w dziejach tegoż ludzkiego oikoumene (resp. ludzkości) $\mathrm{w}$ „Wydarzeniu” Jezus-Chrystus ${ }^{22} \mathrm{i}$ - konsekwentnie - jedynie katolicyzm ośmielił się w odwadze (resp. męstwie) rozumności i racjonalności inteligibilnie uchwycić misterium Trójjedynego ${ }^{23}$. Inne religijne i kulturowo-religijne oikoumene ludzkie zadowoliły się niższymi poziomami racjonalnego uchwycenia swego religijnego fenomenu, zjawiska.

Kiedy więc stawiamy kwestię bezinteresownego poznania, niewyczerpywalnego, nienasyconego (w treściach inteligibilnych) i niezadowalającego się kontemplacją „oglądu rzeczywistości”, sięgającej ostatecznych przyczyn świata osób i rzecz, i zarazem poznania rzeczy niejawnych z Natury (resp. Przyrody), zauważamy niezwykłą zbieżność, jaką uchwycił Akwinata w swej koncepcji teologii jako wiary in statu scientiae - nienasyconego kontemplatywnego poznania zamysłu Stworzyciela, jaki jest dany jako [podmiotowi człowieczemu] pokarm - jako zrozumienie Boga [Trójjedynego], Odwiecznego Słowa stwórczego, Jego postępowania wobec świata, wobec ludzkich oikoumene i wobec każdego ludzkiego podmiotu [każdej osoby] wewnątrz tychże oikoumene.

Dosięgamy tymże zagadnieniem niezwykle istotnej kwestii - ideału niepowtórzonego w jakimkolwiek innym cywilizacyjnym mateczniku ludzkich wspólnot, społeczności czy społeczeństw, jakie w starożytności

22 Zob. D. Kubicki, Owoce dialogu Kościoła lokalnego i uniwersytetu w sytuacji polskich przemian polityczno-ekonomicznych po 1989 roku, ,Teologia Praktyczna” 6:2005, s. 65-78.

23 Zob. J. Ratzinger, Bóg Jezusa Chrystusa. Medytacje o Bogu Trójjedynym [Der Gott Jesu Christi. Betrachtungen über Dreieinigen Gott], tłum. J. Zychowicz, Kraków 1995. 
greckiej stało się udziałem Hellenów, stawiających pytanie filozoficzne i formułujących zarazem podstawy myśli filozoficznej, dotyczącej physis i zawartego w niej oikoumene, które w mediewalnej Christianitas [łacińskiego Zachodu] przybrało niezwykle dojrzałą postać: zinstytucjonalizowanego poszukiwania prawdy (dotyczącej physis: „Natura”, „Przyroda”) - poszukiwania bezinteresownego w niezawisłości intelektu badacza. Retoryczną więc okazuje się kwestia: czy możliwe jest jeszcze większe niezwiązanie ze sposobem ludzkiego uczestniczenia $\mathrm{w}$ osadzeniu w tejże physis wraz z oikoumene, w której się egzystencjalnie odnajduje.

Właśnie w tym olbrzymim zwrocie cywilizacyjnym, jaki dokonał się za przyczyną mediewalnej Christianitas, wynosząc łaciński Zachód ponad wszystkie inne mateczniki cywilizacyjne (w uproszczeniu), $\mathrm{w}$ tymże universitas studiów i zarazem absolutnie bezinteresownego (resp. autonomicznego) prowadzenia badań naukowych miało miejsce niezwykłe wydarzenie, którego sens i znaczenie zdołaliśmy odkryć dopiero współcześnie, jakby w całej pełni postmodernizmu, postnowożytności. Oto bowiem w odnowie filozoficzno-teologicznej (w uproszczeniu) około połowy XX stulecia zdaliśmy sobie dość wyraźnie sprawę z przełomu, jakim było i mogłoby być, gdyby w tym dość jednolitym nurcie zachodnioeuropejskiej myśli filozoficznej było w pełni [w realiach intelektualnych renesansu XIII stulecia] wykorzystane, intelektualne przedsięwzięcie Akwinaty, nawiązującego do Arystotelesa w wykształceniu podstaw realistycznej metafizyki na bazie pojęcia bytu. Powodowało ono, że przedmiotem metafizyki (w koncepcji Akwinaty) jest byt jako rzeczywiście i konkretnie istniejący. Tego najbardziej istotnego novum filozofii Tomaszowej, włączającego istnienie w badania metafizyczne, traktującego je jako ostateczny akt istoty (actus essentiae) i ujmującego Boga jako samoistne istnienie (ipsum esse subsistens) nie zrozumieli uczniowie i słuchacze św. Tomasza, a może i on sam nie zdawał sobie sprawy z ogromu perspektyw koncepcji, jaka stała się jego udziałem ${ }^{24}$.

Możemy jedynie domniemywać, że najpewniej Rousseau nie miałby najmniejszych szans sformułowania i możności postawienia swych [ideologicznych] tez w treści koncepcji „stanu czystej natury” [także ludzkiej], jakie stały się jego udziałem i jakie zostały skwapliwie wykorzystane przez nowożytnych rewolucjonistów „nowej ludzkości, szczęśliwych” społeczności. Najpewniej również nie mielibyśmy problemu

24 Por. S. Swieżawski, O niektórych przyczynach niepowodzeń tomizmu, [w:] tenże, Rozum i tajemnica, Kraków 1960, s. 198-199. 
modernistycznego dylematu, który stanowi treść niniejszych rozważan, a także prezentowanych w tym czasopiśmie artykułów.

Zatem należy się badawczo radować, gdyż poszukiwanie prawdy jako bezinteresowne poznanie rzeczy niejawnych z natury physis nie kroczy wyłącznie drogą - nazwijmy to nietypowo - bez błędów. Współcześnie obecność teologii w strukturze [klasycznego] europejskiego Uniwersytetu jest, oczywiście, szansą zarówno dla samej teologii, jak i dla instytucji nauki, jaką on stanowi. Jako scientia teologia „dysponuje" przecież tak niezbędną innym dyscyplinom nauki całościową ideą świata i człowieka - w sensie możności uzasadnienia ludzkiego (resp. człowieczego) ,jestestwa” perspektywą spełnienia się w Objawiającym - Ponadpodmiotowym i Ponadprzedmiotowym (w uproszczeniu). Nadto posiadając wypracowany intelektualny instrument, a jednocześnie wykorzystując postęp wiedzy wszystkich innych dziedzin nauki, jest w stanie dogłębniej [na sposób teologiczny] rozczytywać sens objawiającego się Słowa w stworzeniu wraz z jego ześrodkowaniem w dziejach ludzkości w „Wydarzeniu” Jezus-Chrystus. Jednak powyższa niezwykle optymistyczna wizja nauk w strukturze europejskiego Uniwersytetu musi pozostać dość mocno przygaszona realiami współczesności postmodernistycznej, która nie wydaje się mieć sama z siebie ani żadnych inteligibilnych instrumentariów, na których to poziomie zdołałaby się ostatecznie i dowodnie przekonać o niepowtarzalności osoby ludzkiej i jej godności, ani żadnej woli czy chęci przezwyciężenia stanu swego nasycenia obfitością jadła, zmysłowej rozkoszy i wygody w globalności społeczeństw konsumpcyjnych. Niestety, wielkość niepowtarzalności ludzkich oikoumene - czyli genialność i zarazem skończoność ludzkiego bytu - polega również na tragiczności losu, jaki na sposób niezdeterminowany może obrać, czyniąc się i czyniąc innych przypadkowymi zaistnieniami - aż po osławione „śrubeczki” szczęśliwych społeczeństw konsumpcji.

Słowa kluczowe: ludzkie oikoumene, inteligibilność zachodnioeuropejska, kultura jako „cień” rzeczywistości, kulturowość, Platoński świat cieni, sens człowieczeństwa, sens physis i oikoumene, twory kultury. 